\title{
KINEMATOGRAFINĖS ATMINTIES REMEDIACIJOS, JŲ RECEPCIJA IR SKLAIDA VISUOMENĖJE
}

\author{
Cinematographic Remediations of Memory, \\ Its Reception and Functioning in Society
}

\author{
SUMMARY
}

Cultural memory as symbolic heritage is objectivizes and externalized in texts, ritual, monuments, commemoration ceremonies, objects, images and other media. Contemporary studies of cultural memory and communication investigate Issues of remediation of cultural memory and communication. Cultural memory functions in different cultural communities depending on media technologies and mediums: printed texts and books, photographic, phonographic, audio-visual records and monuments, memorial sites. The article deals with the social aspects of remediation, communication and reception of cultural memory. Cinematic reflections of the past get particular attention.

\section{SANTRAUKA}

Kultūrinė atmintis - tai simbolinis paveldas, objektyvuotas ir eksternalizuotas tekstuose, ritualuose, paminkluose, paminèjimuose, objektuose, atvaizduose ir kitose medijose. Kultūrinès atminties (re)mediacijos problematika įsitvirtino šiuolaikiniuose kultūrinès atminties ir komunikacijos tyrimuose. Jos tęstinumas ir funkcionavimas įvairiose kultūrinėse bendruomenėse priklauso nuo medijų (technologijų) ar mediumų (tarpininkų) - spausdintų tekstų, fotografinių, fonografinių, audiovizualinių atminties įrašų ir paminklų, memorialinių vietų. Straipsnyje tyrinėjami socialiniai kultūrinès atminties - atminties meno, prisiminimų ¿vaizdinimo - (re)mediacijos, komunikacijos ir recepcijos aspektai. Kinematografinès praeities refleksijos tai archyvinis įsiskverbimas į kolektyvinės atminties teritorijas ir ju paribius - atminties aktualizacijos ir (re)mediacijos vyksmas. 
F ilmo pasirodymo laukè izvairios visuomenès grupès: „kultūrininkai“, politinių kalinių ir tremtinių sajungu atstovai, nukentejusieji nuo sovietinio režimo, besidomintieji nesena istorija. Jo kūrèjai, ruošdami recepcijos lauka, pasitelkè intermedijines strategijas. $2000 \mathrm{~m}$. spali LTV laidoje „Kino pasaulyje“ parodytas siužetas iš filmavimo aikštelès ${ }^{24}$, kuriame kalbejjo režisierius, aktoriai, prodiuseriai ir kt. J. Vaitkaus manymu, filmas suteiks impulsą kitiems kūrëjams ir sudarys bazę kurti kitus filmus, kadangi sukauptas visas kinematografinis arsenalas - aikštelès, bunkeriai, sodyba, ginklai, technika ir kt. Tarsi apsidrausdamas režisierius kalbèjo, kad netgi blogai sukūrus filmą šia temą ji vis tiek traukia žmones, bet norima padaryti gerai, nors šie dalykai neprognozuojami. Daumanto istorija paranki - turi ir dinamika, ir emocija ir intymumą. S. Balandis pažymèjo, kad Lietuva pribrendo šios temos interpretacijai, o B. Bublytė pasidalino savo personažo kuriamo paveikslo ypatumais. Laidos kūrèjų kalbintas Vaidotas Žukas pasakė, kaip svarbu, kad šis filmas rastų vietą šiuolaikinio jauno žmogaus širdyje ir nebūtų vien istorinis. Svarbi aplinkybè, kad filmo herojus i partizanini judejjimą atejjo iš kultūros srities - šiuolaikiniai kultūrininkai neretai šalinasi pilietinių temų ${ }^{25}$.

Filmo „Vienui vieni“" recepcijos laukas pasidalino i dvi priešingas stovyklas. Suvokiantieji filmą kaip istorinès tiesos atstatyma, vertino ypač teigiamai, o kritikai pastebejo nemažai meninès kalbos trūkumų. Živilè Pipinytè rašè: „Jeigu filmo vertè būtų matuojama patriotizmo tankiu vienam kvadratiniam kino ekrano centimetrui, Jono Vaitkaus filmui „Vienui vieni“" (Lietuva, 2004) nebūtų lygių. ${ }^{\text {26 }} \mathrm{Ji}$ kritiškai įvertino filmo veiksmo atitikimą realioms aplinkybėms, personažų charakterių schemiškumą. Autorè taikliai pastebëjo, kad J. Lukšos-Daumanto biografija jau tapusi legenda, idealiai iliustruojančia svarbiausias laikmečio problemas: ,joje susipynè viskas - ir moralinis pasirinkimas, ir šeimos tragedija, kuri neatsiejama nuo to pasirinkimo, ir išdavysčių tinklas, apraizgęs lietuvių idealistus, ir Vakarų reakcija i tai, kas devynerius metus vyko Lietuvoje. Unikalu ir tai, kad Daumantas sugebejjo palikti autentiškus liudijimus“27. Vaidas Jauniškis recenzijoje kaip trūkumus paminejjo istorijos ir scenarijaus nesutapimus, pastarojo silpnuma, dèl kurio sunku sekti ivykių raida, menkas šeimos istorijos sąsajas su bendrais tuometiniais įvykiais, tačiau teigiamai įvertino aktorių vaidybą bei Kipro Mašanausko sukurtą filmo garso takeli. Baigdamas recenziją V. Jauniškis, iškèlęs klausimą, kam skirtas filmas (juodai balta juosta „nežiūroviška“), ir pabrèžęs politinę-ideologinę funkciją, teigia, kad greičiausiai matantiems jame atsaką V. Žalakevičiaus juostai ${ }^{28}$. Galima teigti, kad filmui parinkus antagonistinę intramedijinę retorika, vienpusiškai ir schemiškai plètojant siužetą ir kuriant charakterius, buvo siekiama itvirtinti naują kinematografini pokario naratyvą.

Nepaisant kritiškų atsiliepimų naujienų portaluose ir kultūros leidiniuose, filmas buvo žiūrimas. Rasa Paukštytė aptarè pirmojo nepriklausomybès dešimtmečio Lietuvos kino finansavimą bei sklaidą ir pateikė duomenis, kad $2004 \mathrm{~m}$. „Vienui vieni“ buvo vienas lankomiausių 
filmų (13 vieta $\left.{ }^{29}\right)$ - ji matè apie 23 tūkst. žiūrovų. Tai geriausias tuometinis lietuviško filmo lankomumo rezultatas per visus nepriklausomybės metus. Žinoma, kino žinovai tai siejo ne su menine filmo kokybe, o su išaugusiu susidomejjimu lietuvių kinu bei filmo tema. Tokie skaičiai pranoksta net komercinių juostu rodiklius Lietuvoje ${ }^{30}$. Trisdešimtyje Lietuvos kino teatru parodyti 764 „Vienui vieni“" seansai, 1993-2015 m. Lietuvos kino teatruose rodytų filmų reitingo duomenimis, žiūrovų skaičius išaugo iki 31 147, gauta 77594 EUR pajamų ir užimta 494 vieta $^{31}$. Užsienio lietuvių bendruomenèms buvo surengtos specialios filmo peržiūros. $2005 \mathrm{~m}$. filmas rodytas Europos kinui skirtame renginyje „Euro Cine 25“ Briuselyje bei Europos Sajungos šalių kino festivalyje Čikagoje. Niujorke filmo peržiūra, vykusi Jono Meko įkurto teatro ir antologijos saleje (joje rodomi nekomerciniai filmai), sulaukè žiūrovų dèmesio. N. Bražènaitè-Lukšienè-Paronetto pasakojo apie jo sukūrima, tragišką vyro ir savo pačios gyvenimą. $2004 \mathrm{~m}$. išleista „Vienui vieni“ vaizdajuostè ir DVD - pirmasis Lietuvių filmas skaitmeniniu formatu - kuris papildytas medžiaga, susijusia su filmu, jo kūrimu ir istoriniu laiktarpiu. $2013 \mathrm{~m}$. filmas perkeltas i Youtube ir žiūrètas 15096 kartus. $I M D b$ filmų bazèje filmo reitingas 7,5 (iš 10), lietuviškoje filmų bazejje obuolys.lt kritiku izvertintas $60 \%$, o žiūrovų - 83\%. Filmas buvo remedijuotas - jo intarpai panaudoti Lietuvos gyventoju genocido ir rezistencijos tyrimo centro sukurtame dokumentiniame filme „Partizaninis karas Lietuvoje 1944-1953“ (2004).
Kai filmas buvo demontruojamas didžiuosiuose ekranuose, LTV 2 Lietuvos kino studijoje sukurtų vaidybinių filmų cikle „Retrospektyva“ buvo parodytas filmas „Niekas nenorèjo mirti“ (1965). Saulius Macaitis $2004 \mathrm{~m}$. vasario mènesio laidoje pabrèžè jo gyvybingumą ir pažymèjo, kad jis kelia daugiau diskusijų, nei duoda atsakymų, ir jeigu šis filmas prabėgus beveik keturiasdešimčiai metų dar ne Grūto parke, vadinasi, yra gyvas filmas ${ }^{32}$. Netrukus „Šiaurès Atènuose" pasirodè ir jo komentaras dèl „Vienui vieni“ ir „Niekas nenorèjo mirti“ supriešinimo bei šalies žiūrovų pasidalijimo ì dvi priešiškas stovyklas ${ }^{33}$. S. Macaičio manymu, šių panašios tematikos filmų palyginimai bus neišvengiami, kartu jis prisiminè, kad i „Vienui vienu“" premjerą rudenį susirinko labai specifiška publika. „Kažkoks patriotas pasibaigus filmui sušuko salei: „Iki šiol pasaulis žinojo tik melą apie Lietuvą iš Žalakevičiaus filmo, o dabar jis pagaliau žinos tiesą. Patriotas buvo taip i̇sitikinęs savo teisumu, kad būtų galèjęs stoti dèl to i dvikovą. Bet situacija vis dèlto ne tokia vienaprasmè. Pirma, pasaulis niekada nematè „Niekas nenorejjo mirti“. Filmas buvo rodomas visoje Sovietijoje, na, dar kaimynejje Lenkijoje, bet juk Lenkija - tai dar ne pasaulis." ${ }^{34}$

Dabatai dèl šio filmo periodiškai suaktyveja iki šiol. 2006 m. buvusių politinių kalinių ir tremtinių organizacijos viešai pareikalavo, kad Švietimo ir mokslo ministrè iš programos „Kinas mano mokykloje“", kuria siekiama skatinti vizualini moksleivių raštingumą ir ugdyti kritini mąstymą pašalintų filmą „Niekas 
nenorejo mirti“, nes jis žemina Lietuvos partizanus ir pateisina sovietų terorą ${ }^{35}$. 2016 m. A. Vitkaus dokumentinio filmo "Laikom frontą", kuriame pasakojama apie Antano Lukšos (Juozo brolio) ir MGB agento Juozo Markulio gyvenimo paraleles, pristatymo proga prisimintas tuometinio Lietuvos prezidento Rolando Pakso sprendimas vizito ị Gruziją ir Arméniją metu reprezentuoti šali vežtis ne „Vienui vieni“, o sovietini „šedevrą" "Niekas nenorèjo mirti", kuris sukèlè daug diskusiju televizijoje ir spaudoje $\mathrm{e}^{36}$.

Ši kontroversija bei kinematografinio Lietuvos istorijos įvaizdinimo klausimai aptarinėti akademinėse diskusijose, viešose paskaitose ir seminaruose. $2008 \mathrm{~m}$. balandi Vinco Mykolaičio-Putino muziejuje surengtas seminaras tema „Pokario ekranizacija“, kurị inicijavo muziejaus direktorė Onutė Šorienè, vertejjas ir kino kūrëjas J. Ohmanas. Seminare dalyvavo rašytojas ir dramaturgas Eugenijus Ignatavičius, filmo „Vienui vieni“" prodiuseris Vytautas Vilimas, muziejaus darbuotoja Ula Zaleskytè. Kalbèta apie „Niekas nenorëjo mirti“ ir „Vienui vieni“ kontroversija, kritiškai vertinant V. Žalakevičiaus filmo ideologizmą ir nusižengimą istorinei tiesai ${ }^{37}$.

\section{„PARTIZANO ŽMONA“}

2007 m. Valstybès dienos proga N. Bražènaitè-Lukšienè-Paronetto apdovanota Lietuvos didžiojo kunigaikščio Gedimino ordino Riterio kryžiumi ir ta proga išspausdintas pokalbis tapo įžanga ị naują režisierių V. V. Landsbergio ir A. Marcinkevičiūtès sukurtą meninę-dokumentinę apybraižą „Partizano žmona“ (2011). Ši istorija, Jono Vaiškūno teigimu, yra ,iškalbinga ir paties gyvenimo kino juostai tobulai surežisuota, išsiskirianti simboliškumu ir monumentalumu“ ${ }^{\prime 38}$. Savo namuose JAV ir kelionės po Lietuvą metu nufilmuota N. Bražènaitè-LukšienèParonetto pasakoja atsiminimus, kalbasi su gyvais liudininkais, Aidas Giniotis skaito Daumanto laiškus, kurie susiejami su asociatyviais Lietuvos gamtos vaizdais, rodomos asmeninès fotografijos, atspindinčios kartu praleistą laika, žuvusių partizanų atvaizdai. Filmas parodytas 2012 m. tarptautiniame Vilniaus kino festivalyje „Kino pavasaris", tarptautinia- me Kauno kino festivalyje, surengtos specialios peržiūros kino teatruose, paskelbti pokalbiai su filmo kūrèjais ir herojais. $2012 \mathrm{~m}$. filmas perkeltas i Youtube svetainę ir peržiūrètas 7570 kartų.

Pasakodamas apie filmo atsiradima V. V. Landsbergis prisimena, kad $2000 \mathrm{~m}$. Nijolei atvykus i Lietuvą kartu su Aleksu, Amerikoje gyvenančiu žydu, kuri dar vaiką karo metais iš Kauno geto išgelbèjo Nijolès mama ir brolis, kalbantis su jais, vežiojant po Lietuva, nutarè judviejų prisiminimus nusifilmuoti: „visa tai befiksuodamas supratau, kad mano filme „Baladè apie Daumantą" užčiuopta tik nedidelè šios garbingos Bražènų šeimos istorijos dalelytè. Šeimos, kurioje lemtingai susikryžiavo patys kilniausi ir skaudžiausi XX amžiaus mūsų tautos išbandymai - tarpukario Lietuvos kūrimas, vèliau karas, holokaustas, sovietų okupacija, partizaninis karas, Sibiras, emigracija Amerikon. “39 


\section{LITERATŪRINĖ PARTIZANŲ REMEDIACIJA ROMANE POGRINDIS}

Iš literatūrinių J. Lukšos-Daumanto istorijos remediaciju verta paminèti kanadiečio lietuvių išeivių rašytojo Antano Šileikos romaną Underground (Pogrindis, 2011), kurio vertimas ị lietuvių kalbą pasirodė 2012 m. (išleistas 1500 egz. tiražu). Pasakojimas pagristas tikrais Lietuvos partizaninio karo faktais, o pagrindinio veikejo Luko-Dūmo prototipas - J. Lukša-Daumantas bei jo ir N. Bražènaitès (Monika) meilès istorija ${ }^{40}$. A. Šileika pasakojimui apie kasdieninę patirti, kovas ir traumas pasitelkia patirtinę retorika, detaliai vaizduoja karo po karo - nematomo fronto - kasdienybę, tiesioginès kalbos intarpai sukelia "prisiminimo efektus". Skaitytoją siekiama panardinti i netolimą praeiti, keletoje vietų nukrypstama $i$ atminties ir amnezijos refleksijas (reflektyvios retorikos intarpai). Romanui būdingas žvilgsnis į rezistenciją "iš šalies" ir iš šiu dienų moraliniu pasirinkimu pozicijų. Jis skirtas pirmiausia Kanados skaitytojams, menkai žinantiems apie Baltijos šalių pokario įvykius. Autoriu nuo vaikystès lydejo nevienareikšmės lietuviškumo patirtys ir "ryškiausias ispūdis yra tam tikra egzistencijos problema: draugai klausia, iš kur mes kilę; atsakome, kad iš Lietuvos, o žemèlapyje jos nèra [...] esu iš vietos, kuri neegzistuoja, todèl kartais atrodydavo, kad ir aš pats neegzistuoju. ${ }^{.41}$

Knyga išsamiai pristatyta A. Šileikos internetiniame tinklalapyje ${ }^{42}$, itraukta $i$ geriausių $2011 \mathrm{~m}$. Globe ir Mail renkamu knygu šimtuką ${ }^{43}$. Lietuvos skaitytojai su knyga supažindinti $2013 \mathrm{~m}$. Tarptautinèje Vilniaus knygų mugeje. A. Šileika kal- bèjo apie romano atsiradimo aplinkybes bei motyvus, išsamiai aiškino, kaip kūrè personažus, kokiais dokumentiniais šaltiniais rẻmėsi. Svarbiausias ju - knyga Partizanai ir Lukšos istorija (partizanas Lietuvoje, Paryžiuje ir vèl Lietuvoje), tačiau personažas nèra Lukša. Luko-Dūmo portretą papildo A. Ramanausko-Vanago asmenybe $\dot{e}^{44}$. L. Donskis gyre romaną ir vertino „kaip labai svarbų mūsų intelektualinio gyvenimo faktą [...]. Ne abstrakti, politizuota martirologija ar negyva literatūros "tiesa“, o gyva meninè tiesa ir nesumeluota europietiška istorija atveria Lietuvą ir sau, ir pasauliui. Puikus siužetas ir jaudinančios žmoniu gyvenimo istorijos, o ne didieji valstybiu griūties naratyvai. ${ }^{\prime 45}$ R. Šlapkauskaitè LRT radijo laidoje „Ką man skaityti“" teigiamai ivertino romana, pavadindama ji svarbiu „protezinès" atminties fenomenu ${ }^{46}$.

Literatūros kritikai romaną vertino nevienareikšmiai. Mindaugas Grigaitis, diskusijoje kalbėdamas apie kultūrologinị literatūros sluoksni, jos dalyvavimą kolektyviniu pasakojimu itvirtinime ir transformavime, pabrèžè romano literatūrinių priemonių, kalbos ir stiliaus skurdumą: „,nederètų pamiršti, kad vis délto literatūrai svarbu ne tik tema ir turinys. Kai kalba nužeminama tik iki ideologinio lygmens, manau, tekstas netenka nei vaizduotès žaismo, nei sąmonès sanitarijos lygmens [...]. Šileika sustingsta nesugebejjime emociju atskleisti. Atrodo, kad išeivių rašytojas, peržiūrèjęs daug istoriniu dokumentu, užstringa juose ir raporto stilių ima taikyti literatūrai. Sprogimas, žudymas, gaudymas aprašomas 
administracinei kalbai artimu stiliumi ir neatrodo, kad tai būtu stilistinis sumanymas tokiu rašymu vaizduoti žmogaus atbukimą. Romanas rašomas tarsi raportas, kurio tikslas - suteikti kuo daugiau sausos istorinès medžiagos apie partizanų buití. Veikejjai primena tik negyvas figūras, kurių psichologinis ar egzistencinis gyvenimo lygmuo lieka užgriozdintas po kanceliarinio stiliaus štampais: emocinis fonas apsiriboja žodžiais ,"gera būti šalia", "gera turèti ranką rankoje", "buvo gera pasakoti apie vaikystę" [...], tai ne rašytojo, bet daugiau kronininko tekstas - jis, be abejo, svarbus, nes Vakarų visuomenę supažindina su jiems mažai žinomais ivvykiais, tačiau apie savimonès transformacijas jo kontekste būtu labai sudètinga kalbèti ${ }^{\prime 47}$. Galima sutikti su M. Grigaičiu, kad romanas, pretenduojantis ị istorinès sąmonès ugdymą ar atmintį kuriančią fikcija, yra per silpnas užimti šią vietą. Algimantas Bučys nuosaikiau vertino tiek kritinius pasisakymus, tiek pati romana, teigdamas, kad „lietuviams dar gyva legenda, matyt, užstojo pačios knygos specifiką. O juk angliškai skaitančiai publikai rašantis A. Šileika turejo i̇veikti visiško skaitytojų informacinio nepasiruošimo barjerą" ${ }^{48}$.

Kalbant apie romano recepciją užsienyje reikia paminèti lenkų-kanadiečiu rašytojos Eva Stachniak pokalbị su A. Šileika, kuriame ji taikliai pastebi, jog žvelgiant „iš šalies“ galimas konfliktas tarp romantinio nacionalinio mito ir bandymo jame ižvelgti universalesnę istoriją. Dėl šios priežasties, A. Šileikos teigimu, šią vieną romantiškiausių Lietuvoje tikru gyvenimo istoriju jis pakeitè (Lukas-Dūmas grižta ne pas J. Lukšos-Daumanto metaforiškai vadintą savo "pirmąją žmoną" Lietuvą, o pas tikrą pirmają žmoną) atsižvelgdamas į šiandienini skaitytoją kuriam toks pasiaukojimas dèl tèvynės būtu sunkiai suvokiamas ir tikrieji Lietuvos patriotai, rašytojo teigimu, toki faktu iškraipymą pasmerks ${ }^{49}$. Nenuostabu, kad 2013 m. balandžio 2 d. pasirodè N. Bražènaitės-Lukšienès-Paronetto komentaras, kuriame teigiama, kad „,A. Šileikos žemiška ir ciniška Juozo Lukšos metaforos interpretacija - paprasčiausiai didžiulè nepagarba jo ir visų partizanų atminimui ${ }^{\prime 50}$. Komentare priekaištauta autoriui dèl faktų iškraipymo ir nekorektiško knygu Partizanai ir Laiškai mylimajai panaudojimo - ištiso kai kurių vietu perrašymo.

Vos pasirodžius romanui buvo nupirktos teisès ji ekranizuoti. Filmo scenarijų rašyti ėmėsi tarptautinè komanda dalyvaujant Alvydui Šlepikui ir Australijoje gyvenančiam režisieriui Tomui Donelai, kuris prisipažino, kad kūrinys ji taip sukrètęs, jog nekurti filmo neįmanoma. Režisierius tikisi, kad padedant rašytojui ir tarptautinei kūrybinei komandai, dramatišką Lietuvos pokario ir pasipriešinimo istoriją pagaliau pavyks papasakoti taip, kad ją suprastu ir teisingai ivertintu ne tik lietuviai, bet ir likusi pasaulio dalis ${ }^{51}$.

\section{„NEMATOMAS FRONTAS" DAUGIAMEDIJINIAME KONTEKSTE}

$2014 \mathrm{~m}$. pasirodè režisieriu Jono Ohmano, Vinco Sruoginio ir prodiuserio Marko Johnstono sukurtas dokumentinis filmas „Nematomas frontas“, pasakojantis apie pokario rezistenciją Lietuvoje remiantis J. Lukšos-Daumanto istorija. 
Filmas gausiai dokumentuotas liudininku pasakojimais, nerodytais vertingais archyviniais kadrais. Pokario laiku prisiminimais dalijasi visos pusès: ne tik buvę Lietuvos partizanai, jų ryšininkai, rèmejjai, šeimos nariai, bet ir stribai bei kiti sovietinių saugumo struktūrų atstovai, kovoję su partizanais. Kūrejjai gyvu ginkluoto Lietuvos pasipriešinimo liudytojų, istorinès medžiagos ieškojo ne tik Lietuvoje, bet ir Latvijoje, Lenkijoje, Rusijoje, Švedijoje ir JAV.

Filme, kaip ir „Baladèje apie Daumantą", remedijuotas vienas svarbiausiu liudijimų apie J. Lukšos-Daumanto mirti - J. Pajaujo ir J. Kukausko pokalbis iš laidos „Krantas“ archyvo. Filmo kūrèjai teigè užtrukę trejus metus, kol ji pavyko gauti. V. Sruoginis pažymėjo, kad niekas nenorejo apie ji pasakoti. „Tai buvo sudètinga. Imant interviu, žmonès nenorèjo apie ji šnekèti, nes buvo labai įskaudinti ir jautèsi išduoti. Nesvarbu, ar jie su juo buvo susitikę gyvai, ar ne, jie jautèsi taip išduoti, kad niekas nenorejo apie ji kalbèti. Štai kodèl naudojome seną interviu, kuriame J. Kukauskas kalba. Tai buvo vienintelis kelias, kuriuo galèjome gauti informacijos apie J. Kukauską. Mums prireikè kelerių metų, kol suradome tą interviu, jis padejo papasakoti istorija. ${ }^{\text {.52 }}$ Taip pat filme remedijuotas lyriškas siužetas iš „,Baladès apie Daumantą", kuriame brolis Antanas Lukša girdo ir vèliau paleidžia arklį. Filme kalbinamas JAV senatorius, prezidentas Valdas Adamkus. Nuo kitu kinematografiniu interpretacijų filmą skiria „žvilgsnis iš šalies“ - filmo kūrèjai svetimšaliai. Jie naujai pažvelgè į šią istoriją to laikotarpio pasaulio politiniu ivykiu kontekste, atvirai įvardino ir vaizdžiai iliustravo, kas buvo saugumietis, o kas išdavikas.

Filmo pasirodymas sutapo su naujomis iš Rytų kylančiomis politinėmis grèsmèmis - Rusijos ivvykdyta Ukrainos Krymo aneksija. Kalbejimas apie neseną praeiti tokiu ivykiu konteste Lietuvos žiūrovui tapo nepaprastai aktualus. Pradejjus filmą rodyti didžiosiose Lietuvos kino salèse, pasirodè V. Jauniškio recenzija, kurioje taikliai atskleisti svarbiausi filmo privalumai ir trūkumai. Ypač svarbu, kritiko manymu, kad „filmas buvo taikomas užsienio auditorijai, ir šis pasirinkimas taiklus, nes tai reikalingiau ypač šių dienų Ukrainos ir letarginės užsienio reakcijos i Rusiją kontekste" ${ }^{\text {“53. }}$. Teigiamai įvertinta archyvinès dokumentinès medžiagos gausa ir taikli atranka, tačiau "filmas ima šlubuoti režisuojant tam tikras scenas, per menkai įsižiūrint i žmones, i̇siklausant ${ }^{454}$. Kritikas pastebi, kad filmas padeda atskleisti dar vieną svarbią J. Lukšos-Daumanto asmenybės pusę: „kai Juozas Lukša su Nijole nuotraukose klajoja po Paryžiu ir žiūri architektūrą (nes ją studijavo), kai rašo nuostabius literatūrinius laiškus (puikiai Andriaus Mamontovo perskaityti!) - atsiskleidžia kitas, buvęs galimas šio žmogaus gyvenimas: kultūros, meno žmogaus. O drauge - gerokai platesnio žvilgsnio stratego nei tiesiog jaunuolio, iš sodžiaus patraukusio Tẻvynès ginti“"55. Kritiniu vertinimu išsiskyre kino kritikès Agnès Mackevičiūtès recenzija, kurioje neigiamai atsiliepta apie filmo meninę ir estetinę pusę, pabrèžta, kad filmas paviršutiniškas, menkai atskleista istorija bei heroju charakteriaii ${ }^{56}$. 
2014 m. "Nematomas frontas", parodytas festivalyje „Kino pavasaris“, žiūrovų buvo išrinktas geriausiu - žiūroviškiausiu - lietuvišku filmu, ir Lietuvos kino industrijos apdovanojimų vakare kūrëjams įteikta „Kino pavasario" statulèlè. $2015 \mathrm{~m}$. Sidabrinès gervès apdovanojimuose filmas nominuotas Metų geriausio ilgametražio dokumentinio kino filmo kategorijoje. Filmas rodytas Lietuvos miestų ir miestelių kino teatruose ir salèse, net ir praejjus dviems mènesiams po premjeros, „Nematomas frontas" laikèsi kino teatrų repertuaruose. Per tą laiką filmą pamatẻ beveik 25 tūkst. žiūrovu, gausiai lankè moksleiviai. Jis buvo ittrauktas i edukacini projektą ,"Mokausi iš kino", kuriuo ugdomas kinematografinis raštingumas. Remiantis LKC duomenimis, filmą kino teatruose žiūrèjo 27456 žiūrovai, gauta 106519 EUR pajamų, užimta 357 vieta 1993-2015 m. lankomiausių filmų sąraše ${ }^{57}$. Filmo kūrèjai dalyvavo įvairių kultūros įstaigu rengiamose filmo peržiūrose. Filmą 2015 m. rodė LRT televizija nepriklausomybès atkūrimo dienos 25 metú proga. Taip pat surengti pristatymai JAV Pasaulio lietuvių centre Lemonte, Niujorko lietuvių bendruomenèje, Lietuvos šaulių sajungoje išeivijoje Čikagoje. 2014 m. liepos $11 \mathrm{~d}$. išskirtiniame seanse Pasaulio lietuvių jaunimo suvažiavime „Nematomas frontas" buvo palydètas kelias minutes trukusiomis ovacijomis ${ }^{58}$.

Filmo kūrèjai pasitelkè iprastas ir naujas rinkodaros strategijas. Ivairiuose portaluose paskelbta interviu su filmo kūrëjais ${ }^{59}$, jo heroje N. Bražènaite-Lukšiene-Paronetto ${ }^{60}$, pranešimuose minimi žinomų politikos, kultūros ir kitų sričių žmonių teigiami atsiliepimai. J. LukšosDaumanto našlè dalyvavo ir kalbejo filmo premjeroje Vilniuje ir Kaune. Buvo sukurtas oficialus filmo tinklalapis anglu kalba $^{61}$, panaudotos socialinių tinklų galimybès: Facebook (15 996 paspaudimai „patinka“) paskyroje skelbiamos su filmu susijusios naujienos. Taip pat pasitelktas naujas rinkodaros būdas - pilietinè iniciatyva - žalių juostelių su miško simbolika platinimas, kurios tapo „Nematomo fronto" atributu, skatinančiu pagerbti už Lietuvos laisvę kovojusių partizanų atminimą. Vos pasirodžiusios juostelès iškart išpopuliarejjo. Jas ryšèdami ant rankos padèką miško broliams reiškè daugybė žmonių - nuo žinomų visuomenès veikèju iki moksleivių. 2015 m. filmas išleistas DVD formatu.

\section{IŠVADOS}

Istorinių dokumentų ir archyvų tyrinejjimai, gyvų praeities įvykių liudininkų pasakojimu fiksavimas ir jų „vertimas" i meninę kino ir literatūros kalbą tampa ypač svarbia kultūrinès atminties kūrimo, perkūrimo ir jos sklaidos visuomenejje dalimi. Kinas, literatūra ir kiti menai šiuolaikinio kūrèjo rankose tampa svar- biomis kultūrinę atmintị kuriančiomis medijomis. Šiuolaikinès skaitmeninès vaizdo, garso ar audiovizualinès įrašymo technologijos kuria ir materializuoja naujas atminties formas, kurios iš esmès keičia spausdintą atminties įrašymo kultūrą ir paradigmą. Nuolatinis atminties perrašymas ir pertvarkymas - tai kultū- 
rinès atminties remediacija. Daugiamedijiniuose tinkluose - televizijoje, ivvairiuose internetiniuose kanaluose, socialinėse medijose kuriami kino filmų recepcijos kontekstai, kurių tyrimas leidžia atskleisti, kaip kinas tampa atminties medija. Publikacijos nacionaliniuose ir tarptautiniuose leidiniuose, kino žurnaluose, TV laidos, kino prodiuseriu pasitelkiamos rinkodaros strategijos (specialių peržiūrų rengiamas, DVD versijų išleidimas, rinkos segmentų kūrimas, interviu su prodiuseriais ir aktoriais paskelbimas, istorinio konteksto informacijos pateikimas ir t. t.), apdovanojimai, politiku pasisakymai, akademinès istoriku, filosofu, kultūrologu ir kt. kontroversijos, komentarai ir publikacijos, itraukimas i edukacines programas kuria kino filmo recepcijos lauką ir potencialiai padeda ji formuoti kaip kultūrinès atminties laikmeną. Šis medijose kuriamas recepcijos kontekstas, sudarantis daugiamedijini tinkla, tampa svarbia kultūrinès atminties remediacijos dalimi.

Aptartos ivvairios meninès vertès J. Lukšos-Daumanto istorijos televizinès, kinematografinès ir literatūrinès remediacijos atskleidžia pagrindines pokario naratyvo transformacijas ir šios istorijos virsmą i herojini chrestomatini pasakojimą. Pirmoji kinematografinė V. V. Lands-

\section{Literatūra ir nuorodos}

24 Laidos „Kino pasaulyje“ archyvas. LRT mediateka. Prieiga per internetą: http://www.lrt.lt/ mediateka/irasas/17115 [žiūrèta 201604 22]

25 Ten pat.

26 Živilè Pipinytė, Neperžengti kino barjerai: Jono Vaitkaus „Vienui vieni“" premjera. Delfi.lt. 2004 kovo 2 d. Prieiga per internetą: http://www.delfi.lt/veidai/kinas/neperzengti-barjerai-jono-vait- bergio „Baladè apie Daumantą“ - romantinis epas, $\mathrm{XX}$ a. 9 deš. viduryje pradèjęs kurti naują pokario pasakojimą ir tapęs svarbia šios istorijos vaizdavimo schemata bei archyviniu dokumentu, kurio ištraukos pakartojamos vèlesnèse remediacijose. Po aštuonerių metų sukurtas J. Vaitkaus vaidybinis dokumentinis filmas "Vienui vieni“ tapo veikiau atsaku V. Žalakevičiaus „Niekas nenorejo mirti“ (1965), kuriame kino kalba tvirtinamas naujas pokario naratyvas antagonistine intramedijine retorika, vienpusišku ir schemišku siužetu ir charakteriais. V. V. Landsbergio „Partizano žmona" (2011) - lyriška subtili kelionè i praeiti, pasakojama N. Bražènaitès lūpomis. A. Šileikos romanas Pogrindis (2012) ir filmas "Nematomas frontas" (2014) atvertè naują pokario rezistencijos ir J. Lukšos-Daumanto asmenybès interpretacijos puslapi. Juose i šią istoriją pažvelgta iš šalies, neturint tiesioginio sąlyčio su ja, adresuojant ją pirmiausia ne Lietuvos, o užsienio skaitytojui ir žiūrovui. Romane istorija transformuota ir pritaikyta nūdienos realijoms bei gyvenimo sampratoms, filme sukurtas herojinis pasakojimas leidžia pažvelgti i Lietuvos pokari iš šalies pasaulio ivvykių kontekste. Visos šios remediacijos padeda kurti ir palaikyti kultūrinę atmintį.

\footnotetext{
kaus-filmo-vienui-vieni-premjera.d?id=3847624 [žiūrèta 201606 06]

27 Ten pat.

28 Vaidas Jauniškis, Niekas nenorëjo liautis. Tv3.lt. 2003 liepos 8 d. Prieiga per internetą: http:// www.tv3.1t/naujiena/285112/vaido-jauniskiokulturos-metro-niekas-nenorejo-liautis [žiūrèta 201606 06]
} 
${ }^{29}$ Lietuvos kino teatruose rodytu filmu topas (1993-2015 m.). Lietuvos kino centras. Prieiga per internetą: http://www.lkc.lt/wp-content/uploads/ 2014/10/Lietuvos-kino-teatruose-rodytu-filmutopas-1993-2015-m.1.pdf [žiūrèta 201606 02]

30 Rasa Paukštytè, Lietuvių kinas 1990-2003. Lfc.lt 2004 liepos 19 d. Prieiga per internetą: http:// www.lfc.lt/lt/Page=ArticleList\&ID=1118 [žiūrèta 201606 02]

${ }^{31}$ Lietuvos kino teatruose rodytu filmu topas (1993-2015 m.). Lietuvos kino centras. Prieiga per internetą: http://www.lkc.lt/wp-content/uploads/ 2014/10/Lietuvos-kino-teatruose-rodytu-filmutopas-1993-2015-m.1.pdf [žiūrèta 201606 02]

32 Laidos „Retrospektyva“ archyvas. Prieiga per internetą: http://www.lrt.lt/mediateka/irasas/8714 [žiūrèta 201606 30]

33 Saulius Macaitis, Niekas nenorèjo mirti. Šiaurés Aténai. 2004 vasario 28 d. Prieiga per internetą: http://eia.libis.lt:8080/archyvas/viesas/20110110 052157/http://www.culture.lt/satenai/?leid_id= 690\&kas=straipsnis\&st_id=2467 [žiūrèta 2016 $0701]$

${ }^{34}$ Ten pat.

35 Andrius Sytas, Politiniai tremtiniai reikalauja mokiniams nerodyti filmo „Niekas nenorèjo mirti“. Alfa.lt. 2006 lapkričio 16 d. http://www. alfa.lt/straipsnis/89325/politiniai-tremtiniai-reikalauja-mokiniams-nerodyti-filmo-niekas-nenorejo-mirti\#ixzz4F7jrpzTH [žiūrèta 201605 05]

36 Žurnalistas R. Valatka stebejosi Prezidento sprendimu, nes "Niekas nenorëjo mirti“ aiškiai „Šlovina kagèbistus ir reabilituoja stribus. Kaunas, Povilas. Pasitikejjimo, išdavystės ir kraujo pėdsakais. LŽS nario A. Vaitkaus filmo pristatymo proga. Kaunozurnalistai.lt. 2016 vasario 29 d. Prieiga per internetą: http://www.kaunozurnalistai.lt/35864/ [žiūreta 201606 07]

37 Žilvinas Radavičius, Sostinès inteligentija diskutavo apie pokario ekranizaciją. Lietuvos rytas. 2008 balandžio 13 d. Prieiga per internetą http:// kultura.lrytas.lt/-12080705861205978525-sostin\% C4\%97s-inteligentija-diskutavo-apie-pokarioekranizacij\%C4\%85.htm?utm_source=lrExtra Links\&utm_campaign=Copy\&utm_medium= Copy [žiūrèta 201609 05]

38 Jonas Vaiškūnas, Filmas „Partizano žmona“ gyvas istorijos vëjas. Delfi.lt. 2011 rugsëjo 29 d. Prieiga per internetą: http://www.delfi.lt/news/ ringas/lit/jvaiskunas-filmas-partizano-zmonagyvas-istorijos-vejas.d?id=50098000 [žiūrèta 201609 05]
39 Vytautas V. Landsbergis, Partizano žmona. Bernardinai.lt. 2007 liepos $18 \mathrm{~d}$. Prieiga per internetą: http://www.bernardinai.lt/straipsnis/200707-18-partizano-zmona/4430 [žiūrèta 201606 11]

40 Antanas Šileika, Pogrindis. Iš anglų k. vertè Irma Šlekytè. Vilnius: Versus aureus, 2012.

${ }^{41}$ Ramūnas Čičelis, Antanas Šileika: esu vaizduotès emigrantas. Bernardinai.lt. 2013 kovo16 d. Prieiga per internetą: http://www.bernardinai. 1t/straipsnis/2013-03-16-ramunas-cicelis-antanassileika-esu-vaizduotes-emigrantas/97347 [žiūrèta 201608 05]

42 www.antanassileika.ca

43 Richard Handler, Notes from the 'Underground' of Antanas Sileika's life. Cbc.ca. November 29, 2011. Prieiga per internetą: http://www.cbc.ca/ news/canada/notes-from-the-underground-of-antanas-sileika-s-life-1.1117059 [žiūrèta 201607 07]

44 Antanas Šileika pristato romaną „Pogrindis“. Literatūra ir menas. Mediateka. Prieiga per internetą: http://literaturairmenas.lt/mediateka/942antanas-sileika-pristato-romana-pogrindis [žiūrèta 201609 02]

${ }^{45}$ Leonidas Donskis, Reikejjo gyvam susideginti, kad Lietuvos buvimas taptų faktu. Delfi.lt. 2013 kovo 22 d. Prieiga per internetą: http://www. delfi.lt/news/ringas/lit/ldonskis-reikejo-gyvamsusideginti-kad-lietuvos-buvimas-taptu-faktupasauliui.d?id=60968331 [žiūrèta 201607 05]

46 Rūta Šlapkauskaitè, Apie partizanus ir protezinę atmintį: A. Šileikos romanas „Pogrindis“. Lrt.lt. 2014 balandžio 19 d. Prieiga per internetą: http:// www.lrt.lt/naujienos/nuomones/10/41102 [žiūrèta 201606 05]

47 Apie istoriją literatūroje. Diskutuoja Mindaugas Grigaitis, Simona Siderevičiūtè, Urtẻ Sakalytè, Loreta Varaniūtè ir Urtè Navalinskaitè. Kamanè. lt. 2013 birželio $17 \mathrm{~d}$. Prieiga per internetą: http:// www.kamane.lt/layout/set/print/Kamanestekstai/2013-metai/Birzelis/Literatura/Apie-istorija-literaturoje [žiūrèta 201606 06]

48 Požiūriai. Algimantas Bučys. "Metų" anketa. Metai. 2014, Nr. 7. Prieiga per internetą: http:// www.tekstai.lt/zurnalas-metai/7701-poziuriaialgimantas-bucys [žiūrèta 20160608 ]

49 Eva Stachniak in Conversation with Antanas Sileika. Evastachniak.com. February 16, 2011. Prieiga per internetą: http://www.evastachniak. com/2011/02/16/eva-stachniak-in-conversationwith-antanas-sileika/ [žiūrèta 201606 22]

${ }^{50}$ Nijolès Bražènaitės-Lukšienès-Paronetto - legendinio partizanu vado Juozo Lukšos-Dau- 
manto žmonos įspūdžiai perskaičius Antano Šileikos romaną „Underground“ (Pogrindis). Vytauto V. Landsbergio pokalbis su Nijole Bražènaite-Lukšiene-Peronetto. Bernardinai.lt. 2013 balandžio $2 \mathrm{~d}$. Prieiga per internetą: http://www. bernardinai.lt/straipsnis/2013-04-02-nijole-brazenaite-luksiene-paronetto-dar-vienas-istorinisromanas/98422 [žiūrèta 201606 11]

51 Antano Šileikos „Pogrindis“ - lietuviu pasipriešinimo bei meilès istorija. Bernardinai.lt. 2012 spalio 25 d. Prieiga per internetą http://www. bernardinai.lt/straipsnis/2012-10-25-antano-sileikos-pogrindis-lietuviu-pasipriesinimo-bei-meiles-istorija/89871 [žiūrèta 201606 12]

52 Mindaugas Jackevičius, Po filmo apie partizanus: niekas nenorëjo pasakoti apie išdaviką. Delfi.lt. 2014 rugpjūčio 13 d. Prieiga per internetą: http:// www.delfi.lt/news/daily/lithuania/po-filmo-apiepartizanus-niekas-nenorejo-pasakoti-apieisdavika.d?id=65546392 [žiūrèta 201607 05]

53 Vaidas Jauniškis, Nematomo fronto pusès. Lfc.lt. 2014 rugpjūčio15 d. Prieiga per internetą: http:// www.lfc.lt/lt/Page=ArticleList\&ID=11684 [žiūrèta 201606 12]

54 Ten pat.

55 Ten pat.

56 Agnè Mackevičiūtė, Žvilgsnis į nematomą frontą. Žurnalaskinas.lt. 2014 liepos 24. Prieiga per internetą: http://www.zurnalaskinas.lt/musukinas/2014-10-01/Nematomas-frontas [žiūrèta $20160522]$

57 Lietuvos kino teatruose rodytų filmų topas (19932015 m.). Lietuvos kino centras. Prieiga per interne- tą: http://www.lkc.lt/wp-content/uploads/2014/ 10/Lietuvos-kino-teatruose-rodytu-filmu-topas1993-2015-m.1.pdf [žiūrèta 201606 02]

58 Filme "Nematomas frontas" partizanu lyderio Juozo Lukšos žodžius taria Andrius Mamontovas. Vakaru ekspresas, 2014 liepos 22 d. Prieiga per internetą: http://www.ve.lt/naujienos/kultura/filmai/filme-nematomas-frontas-partizanulyderio-juozo-luksos-zodzius-taria-andrius-mamontovas-1216037/ [žiūrèta 201606 02]

${ }_{59}$ Mindaugas Jackevičius, Po filmo apie partizanus: niekas nenorejjo pasakoti apie išdaviką. Delfi.lt, 2014 rugpjūčio 13 d. Preiga per internetą: http://www.delfi.lt/news/daily/lithuania/pofilmo-apie-partizanus-niekas-nenorejo-pasakotiapie-isdavika.d?id=65546392 [žiūrèta 201609 02]; Filmas "Nematomas frontas" apie Lietuvos partizanini pasipriešinimą pristatytas Niujorke. Fimo kūrejus kalbina Austèja Masiokaitè. Bernardinai.lt, 2012 rugsèjo $16 \mathrm{~d}$. Prieiga per internetą: http://www.bernardinai.lt/straipsnis/201209-16-filmas-nematomas-frontas-apie-lietuvospartizanini-pasipriesinima-pristatytas-niujorke/88004 [žiūrèta 201609 02]

${ }^{60}$ Lina Grikevičienė, Partizano Juozo LukšosDaumanto žmona: „Nepatogaus laiko meilei nèra“. 15min.lt, 2014 rugsèjo $6 \mathrm{~d}$. Prieiga per internetą: http://www.15min.lt/ji24/straipsnis/ laisvalaikis/partizano-juozo-luksos-daumantozmona-nepatogaus-laiko-meilei-nera-566-449208 [žiūrèta 20160702 ]

${ }^{61} \mathrm{http}: / /$ www.theinvisiblefront.com [žiūrèta 2016 07 24] 